Socialist Studies / Études socialistes 7(1/2) Spring/Fall 2011: 42-64

Copyright (C) 2011 The Author(s)

SPECIAL ISSUE ON ORGANIZING FOR AUSTERITY: THE NEOLIBERAL STATE, REGULATING LABOUR AND WORKING CLASS RESISTANCE

\title{
Austerity for Whom?
}

\section{STEPHEN McBRIDE and HEATHER WHITESIDE}

Political Science, McMaster University. Hamilton, Ontario, Canada.

Political Science, Simon Fraser University. Burnaby, British Columbia, Canada.

\begin{abstract}
In contrast to the recent multi-billion dollar bailouts offered to leading sectors of capital, fiscal austerity is poised to make a comeback worldwide. Labour will be forced to pay for the public debt accumulated in the aftermath of the recent global financial and economic crisis. Notwithstanding change and evolution in the neoliberal model over time, this return to austerity is consistent with overall policy in the neoliberal period which can be considered an era of permanent restraint in most areas of social spending. This article examines a variety of trends that have emerged over the past thirty years of neoliberal rule: the various facets of neoliberal policy and their temporal dimensions; as well as the results of market-reliance and spending reforms: growing affluence for a minority of Canadians while the majority lose ground and inequalities are further entrenched. Asking 'austerity for whom' directs attention at the interconnections between affluence and austerity that exist in Canada.
\end{abstract}

\section{Résumé}

Contrairement aux récents plans de sauvetage impliquant des milliards de dollars offerts aux principaux secteurs de l'économie, l'austérité budgétaire s'apprête à faire un retour à l'échelle planétaire. Les travailleurs n'auront d'autre choix que de rembourser la dette publique engendrée à la suite de la récente crise économique et financière mondiale. Malgré le changement et l'évolution dans le modèle néo-libéral au fil du temps, ce retour à l'austérité concorde avec la politique globale de la période néolibérale pouvant être considérée comme une époque de restrictions permanentes touchant la plupart des domaines de dépenses sociales. Cet article examine une série de tendances ayant émergé au cours des trente dernières années du pouvoir néolibéral: les différents aspects de la politique néolibérale et leurs dimensions temporelles, ainsi que les résultats du recours au marché financier et de la réforme du contrôle de la dépense: forte croissance d'une minorité de Canadiens alors que la majorité perd du terrain enracinant davantage les inégalités. La question « l'austérité pour qui? » dirige l'attention vers l'interconnexion entre l'affluence et l'austérité qui existent au Canada.

\footnotetext{
Stephen McBride is Professor of Political Science and Canada Research Chair in Public Policy and Globalization at McMaster University. Heather Whiteside is a doctoral candidate in the department of Political Science at Simon Fraser University
}

Stephen McBride est Professeur en Sciences Politiques et Chaire de recherche du Canada sur les politiques publiques et la mondialisation à l'université McMaster. Heather Whiteside est un candidat au doctorat au département des Sciences Politiques à l'université Simon Fraser. 
McBRIDE and WHITESIDE: Introduction: Austerity for Whom?

\section{Keywords}

Austerity; Canada; crisis; neoliberalism

\section{Mots Clés}

Austérité; Canada; crise; néolibéralisme

Austerity, meaning "the quality or state of being austere" and "enforced or extreme economy," was named by the Merriam Webster dictionary as its Word of the Year for $2010 .{ }^{1}$ In the aftermath ${ }^{2}$ of the deep financial and economic crisis that began in 2007, most governments and international organizations started to emphasise that the bailouts and financial stimulus that they had enacted as a response to the prospect of financial and economic meltdown would now have to be paid for. In practice, under the neo-liberal paradigm that for policy-making elites has retained its dominant position, austerity means an economic and social policy based on "deficit cutting, slashed spending and the mysterious evaporation of benefits" (Elmhirst 2010). Unsurprisingly, austerity is also on the minds of the web-browsing public.

However, a casual survey of press coverage of spending cuts and the continuation of rewards to financial operatives, through bankers' bonus payments for example, ${ }^{3}$ leads to the conclusion that austerity can hardly be the only defining characteristic of our age. At the very least, we need to ask: "Austerity for Whom?" - a question that carries with it the connotation that if it is austerity for some, it will be affluence for others (see McBride and Whiteside 2011). Nevertheless, though the word itself has achieved greater prominence as a result of the 2007 crisis, there is a sense in which austerity for some has been a permanent feature of the neoliberal era. Still, neoliberalism has undergone changes and moved through a number of stages since it began to dominate political discourse. One aim of this article is to chart elements of continuity whilst also being sensitive to new developments and discontinuities in the long period of neoliberal hegemony.

\footnotetext{
${ }^{1}$ For one of many articles reporting this event see Contreras (2010).

2 "Aftermath" is used conditionally -- opinions differ on whether that crisis is truly over.

${ }^{3}$ To give just one example, in the UK it was revealed in February 2011 that bankers' bonuses for 2010 would likely total $\mathrm{f6}$ billion (BBC 2011); a few months earlier, in October, the Chancellor, George Osborne, had identified $f 7 \mathrm{bn}$ in extra welfare cuts, including changes to incapacity, housing benefit and tax credits, amongst broader public sector reductions totaling f81 billion (BBC 2010).
} 
The rise of neoliberalism in the 1970s was accompanied by various claims that led to the conclusion that the state, especially in its role as guarantor of full-employment and adequate social provision, should be reduced in size and the beneficiaries of these activities be made more reliant on their success in a less regulated market. The 1970s "stagflation" crisis was frequently framed in terms of "wage-push" inflation, a formula suggesting that labour had become too powerful and that its wage demands were destabilizing the system through creating inflationary pressures.

Considered either as an accumulation strategy or as a policy paradigm, neoliberalism's objectives were drastic. Its primary objective was not to contain labour, but to roll back the gains it had made in the post-war period. This could occur directly through confrontations at the bargaining table, in a context where tight monetary policy to fight inflation had disciplined labour through increasing unemployment. Or, it could occur indirectly through diminishing the state's provision of the "social wage" provided through various social programs. In this early period, "restraint" or, sometimes "retrenchment" was the preferred descriptor for policies that fit the definition of austerity. Playing with a common definition of politics as "who get what, when, where, how?", the politics of restraint was once described as " who gets none or who gets less of what, when and how?" (Maslove, Prince and Doern 1986, 205).

Born in the battle against inflation, neoliberalism proved inventive in attaching itself to new justifications as time proceeded. As inflation declined, the fight against it ceded priority to the size of government budget deficits as a rationale for neoliberal policies. Essentially the project of reducing public deficits/debt and inflation control served a similar policy agenda. Thus, although neoliberalism has proved flexible and opportunistic in supplying arguments, and in effecting some changes in its policy package, we argue that it has been quite principled and unwavering in its objectives and instruments, chief among them are the agenda of reducing and transforming the role of the state and redistributing income, wealth and power from labour to capital.

\section{Neoliberalism in Canada}

Over the past few decades the neoliberal policy paradigm has emphasized budgetary austerity, implementation of regressive taxation, tax cuts for corporations, de-/re-regulation in a wide range of areas previously subject to regulation, privatization in various forms ranging from sale of assets to the implementation of public-private partnerships, public sector reform 
through adopting market-like processes such as New Public Management, and liberalization of the economy, in part through the adoption of free trade agreements. Virtually every substantive policy area - from industrial relations and employment standards, social welfare policy, employment insurance, education, through to monetary policy and foreign policy reveals some impact.

Jamie Peck and Adam Tickell (2002) have provided a useful for framework for analysing the various stages of neoliberalism, though these should be considered heuristically, rather than as chronological. In its first stage, neoliberalism began as an intellectual project, as a critique of the post-war Keynesian orthodoxy. Secondly, in response to global stagflation it evolved into a political program in the hands of right wing politicians such as the Ronald Reagan, Margaret Thatcher, and Brian Mulroney. This phase, Peck and Tickell describe as 'roll-back' neoliberalization. The term refers to the process of tearing down the old Keynesian policy system through the introduction of monetarism, budget and social spending cuts, regressive taxation, privatization, and deregulation which all became reigning policies of the day.

Though the stages should not be understood as being strictly chronological rolling back the Keynesian legacy did preoccupy the first decade, at least, of neoliberal governments in office. The focus was largely on modifying the policies and programs that had defined Keynesianism. This process was highly contested and even if defenders lacked a sustainable alternative vision of how to manage the post-Keynesian political economy, they could be tenacious in the defence of the benefits it had brought. Thus, success was not guaranteed, and neoliberal governments for the most part proceeded gradually in their practice, even if their rhetoric at times suggested otherwise. Common techniques included transforming universal into selective programs, tightening eligibility requirements to qualify for some benefits like unemployment insurance, imposing ceilings on program costs-or, alternatively, making them self-financing or subject to "clawbacks" over a certain benefit level (Houle 1990). Stephen Phillips (2000, 5-6) noted that in 1979 universal programs paid out 43 percent of income security benefits and, by 1993, zero percent. Thus, the ways neoliberal reform got implemented varied over time and between policy areas, depending on who had jurisdiction in federal systems (Banting 2005) and also on how much popular support programs enjoyed. Moreover, implementing the neoliberal paradigm has proven crisis prone (McBride and Whiteside 2011, Chapter 5), and responding to these crises has necessitated policy learning and adjustment. 
There is also comparative evidence (see Hacker 2004) that during this period considerable incremental change was happening that altered the landscape of social policy in the direction of stringency and austerity even prior to the more rapid changes that, in Canada, resulted from the 1995 federal budget. Certainly, the picture of relentless incremental change applies to some policy areas in Canada such as unemployment, since renamed employment insurance (see McBride 1992 Chapter 6; Campeau 2005), and industrial relations (see Panitch and Swartz 2008; Fudge 2005). This agenda went hand-in-hand with the drive for flexibility for employers, a process in which, as Guy Standing $(1999,81)$ famously noted, "fear changed sides".

Though political and economic elites had no use for an active state, save in strictly delimited areas that promoted the neoliberal agenda, polling evidence through the mid-1990s continued to show public preference for such a state with job creation and protection of social programs central to its mandate (see McBride and Shields 1997, 78-9). In this context, public and social movement opposition to the neoliberal agenda was not ineffective. In the late 1980s there were signs that the institutions of the Keynesian welfare state were proving resilient (Banting 1987; Mishra 1990). These findings were consistent with comparative evidence on welfare state resilience (see Beland and de Chantal 2004; Pierson 1994; Torfing 2001) and varieties of capitalism (Hall and Soskice 2002). The precise impact of the Mulroney government on existing programs remained a matter of debate in the 1980s and early 1990s. The prevailing view in Canada was that change was incremental and consisted of erosion rather than outright dismantling (Banting 1987, 213); the accumulation of incremental change was, however, setting the scene for more radical departures and in Canada the deep recession of the early 1990s and ensuing budget deficits provided the occasion.

Similarly, the escape from the 'national' to the 'global' really only took hold in the mid-1990s, some twenty years after the dominance of neoliberalism began to be asserted. The 1989 Canada - United States Free Trade Agreement was an early indicator of this, but the main developments took place later, with the implementation of the North American Free Trade Agreement and the advent of the World Trade Organization. These international economic treaties have been variously described - as instruments of "disciplinary neoliberalism" (Gill 1995), as new or quasi-constitutions (Clarkson 1993), and as "conditioning frameworks" (Grinspun and Kreklewich 1994). Whatever the label, the thrust of the analysis was that the political effect of these economic 
agreements was to enhance and embed and "lock-in" economic liberalism and to render it more difficult for states to alter market relations. ${ }^{4}$

The 1995 federal budget is widely acknowledged to have marked a fundamental shift in the role of the federal state in Canada. Erosion of social programs ended; demolition began (Prince 1999; Kroeger 1996). Henceforth, the primacy of deficit reduction over maintenance of the social safety net was absolutely clear. This led to declining federal transfers to provinces and a fundamental redesign of the unemployment benefit system. As federal funding was diminished, so too were the federal conditions attached to the funds. This enabled provinces to re-design their assistance programs and, as they implemented their own budget cutting exercises, to impose a harsh regime of austerity on recipients of social assistance.

From the mid-1990s Peck and Tickell's third stage of the neoliberal project - "roll-out" began to emerge. Policies associated with this stage included: social program reform (rather than simply program cuts), tax expenditures as new forms of the welfare state (rather than removing all support), establishing partnerships with the private sector (rather than full-scale privatization), and re-regulation (rather than deregulation). The "roll-back" and "roll-out" distinction is an important one to make because it demonstrates the ways in which the neoliberal project has evolved over the years, often out of a need to deal with the contradictions and dislocations that result from its hallmark austerity. However, it would be misleading to suggest that the "roll-out" phase does not itself promote austerity. Indeed, as will be shown in the latter portions of this article, in the cases of income, wealth, government employment, and privatization, austerity is intrinsic to the process. They illustrate the way austerity and

\footnotetext{
${ }^{4}$ Similar initiatives were undertaken at the domestic level though, in Parliamentary systems where the constitutional doctrine holds that no Parliament can bind its successor, these tended to be symbolic rather than binding. This, for example was true of attempts to impose balanced budget legislation. If successful, balanced budget legislation, or similar laws which limit fiscal policy making powers, would effectively eliminate the ability of government to spend during downturns. Given that tax increases were also discouraged, or capped through legislation, the effect would be to remove the Keynesian policy option. Balanced budget legislation was enacted in most provinces and territories across Canada in the 1990s. Spending cuts were thus encouraged by attempting to lock-in place neoliberal reasoning, and tie the hands of future governments, should they seek to promote greater social equity and full employment. However, it must be noted that the recent economic crisis has prompted at least a temporary reprieve from inflexible balanced budget legislation.
} 
Socialist Studies / Études socialistes 7(1/2) Spring/Fall 2011: $42-64$

affluence have co-existed in the neoliberal experience and, if current trends continue, will continue to do so.

\section{Transformations in Neoliberalism}

Despite the preference for austerity that runs throughout the neoliberal period (regardless of the political party holding power), thinking in terms of phases - or the temporal dynamics of neoliberalization - can be a very fruitful exercise, revealing changes within this paradigm as it evolves to deal with the problems of legitimacy, social reproduction, and social and economic instability that are created by its efforts to tear all down barriers to capital accumulation. Peck and Tickell's (2002) roll-back and roll-out description of this process referred to above is but one example. By the early 2000s other interesting theories were beginning to emerge as well 'inclusive liberalism' and the 'social investment approach' for instance.

Porter and Craig (2004) and Mahon (2008), for example, argue that global governance institutions like the Organisation for Economic Cooperation and Development and World Bank began to modify their policy position in the 1990s by adopting a new approach - dubbed 'inclusive liberalism' - which is distinct in some ways from earlier forms of neoliberalism. Inclusive liberalism shares important features with neoliberalism (such as an emphasis on the individual, an allegiance to a capitalist market economy and the protection/expansion of private property, an emphasis on supply side measures such as taxation, and flexibilization of the labour market), however Mahon $(2008,262)$ argues that these two approaches draw on different elements of classical liberalism, with inclusive liberalism being more oriented toward social liberalism and thus focused more on redesigning the welfare state than on dismantlement. These new reforms emphasize assistance and support services, especially with respect to taxation and benefits received, and invest in human and social capital. These ideals were absent from neoliberal paradigm in its early stages (Graefe 2006).

Porter and Craig $(2004,390)$ call this a "re-embedding, securing phase in contemporary liberal hegemony." Importantly, there is a defensive component to this new phase as neoliberalism failed in many ways to develop the components necessary to produce the social fix needed to promote widespread prosperity and stability following the global accumulation problems that began in the 1970s (see Jessop 2006). This resulted in the 'lost decade' of international development experienced in the 1980s, the many debt and financial crises witnessed as a result of neoliberal policies, the erosion of social support, and the rise of violent 
protests against neoliberal austerity and free trade; all of which created serious social instability and a failure of neoliberalism to gain widespread legitimacy (Porter and Craig 2004, 391).

Similarly, with domestic policy transformations, Jenson and Saint Martin (2003) argue that growing concern with the social cohesion problems induced by earlier neoliberal reforms prompted an evolution of social policy in the 1990s. They call this new line of thinking the 'social investment approach', which adds an emphasis on social investment and human capital formation to older neoliberal policy elements. In their words, "high rates of inequality, low wages, poor jobs, or temporary deprivation are not a serious problem in and of themselves: they are so only if individuals become trapped in those circumstances or if they foster anti-social, exclusionary behaviours, such as criminality, dropping out, and so on. They become important when they affect future life chances or social cohesion in the present" (Jenson and Saint Martin 2003, 92). Thus the social investment approach is not only a departure from the post war era distributive or consumption-oriented welfare state, but it is also a modification of the neoliberal paradigm.

Although distinct, the common thread that runs throughout descriptions of roll-out neoliberalization, inclusive liberalism, and the rise of a social investment approach is the recognition that by the late 1990s the search was on for how to make greater market-reliance ${ }^{5}$ a viable and sustainable political project in the long run. One important factor that has inhibited this search from becoming a transition away from neoliberalism, rather than being a change within neoliberalism, is that any new policy thinking and program redesign has continued to operate within the context of strict neoliberal fiscal austerity. ${ }^{6}$ Thus when evaluating whether neoliberalism has been displaced by these new models, or whether these represent varieties of neoliberalism, it is useful to keep in mind Joseph Schumpeter's insightful quip that the public budget is the 'skeleton of the state stripped of all misleading ideologies'. We therefore understand the rise of inclusive liberalism or new social investment approaches as new faces of the neoliberal project rather than rival paradigms.

\footnotetext{
${ }^{5}$ For example, Jenson and St. Martin $(2003,94)$ point out that in Canada 'in-work benefits' are the new instrument of choice, where government covers the difference between needs and market income by adopting a strategy of "making work pay" (e.g., the federal Canada Child Tax Benefit and similar provincial child tax benefits).

${ }^{6}$ For example, see the section on welfare incomes below.
} 
As the statistics examined in the following sections clearly indicate, to whatever extent decision makers may have articulated new policy models, it has not led to an actual improvement in the in the material conditions of most Canadians. For some indicators of overall social wellbeing (e.g., income distribution and public sector employment), gains made in the 2000s have only managed to partially restore what was stripped away in the 1980s and 1990s; while for other indicators (e.g., welfare incomes, wealth distribution, and real wages), austerity and market-reliance has led to an entrenchment of inequalities. Altogether this suggests that despite the interesting temporal dynamics at play during the neoliberal period, it remains consistently marked by fiscal austerity, deterioration in the position of the majority (the middle class in particular), and rising affluence for a minority of Canadians.

\section{Income Distribution}

In a market-based society, one's standard of living is largely dependent on income secured through the labour market, a reality made all the more conspicuous due to the neoliberal erosion of the welfare state through fiscal austerity and program reform. Disparities in income distribution are a good indicator of the relative level of fairness and wellbeing in a society. As disparities rise, so too do inequalities. The statistical data accumulated over the neoliberal period in Canada clearly indicates that income disparities are on the rise (with both market and after-tax incomes); and gains from economic growth are being disproportionately captured by those most well off (and to an increasing degree).

\section{Rising Income Disparity}

Incomes have risen in Canada over the past thirty years, with the average market income increasing by nearly 17 percent, from $\$ 54,300$ in 1978 to $\$ 63,300$ in 2008 (in 2008 constant dollars). ${ }^{7}$ However, gains from rising incomes have been disproportionately captured by the highest earners. Two ways to track these changes are by comparing the average earnings of income quintiles over time, and by examining changes in the share of market income captured by each quintile. Both indicate rising income disparity in Canada.

First, members of the highest income quintile made 35 percent more in 2008 than they did in 1978 (an increase of $\$ 42,500$ ), while the

\footnotetext{
${ }^{7}$ Market income is composed of earnings wages, salaries and commission, self-employment income, farm income, investment income, retirement pensions.
} 
McBRIDE and WHITESIDE: Introduction: Austerity for Whom?

lowest quintile made only 6 percent more (an increase of \$200). Midrange incomes ( 60 percent of Canadians) nudged up slightly, increasing by 1.5 percent (an increase of $\$ 2,200$ (see Table 1)). Averaged over the thirtyyear period, income-earners in the lowest quintile achieved a derisory \$6-7 per year increase in real incomes. Moreover, the increases for most people were concentrated in the final years of the 2000s boom, just before the economic crisis hit. The bottom sixty per cent of income-earners were substantially worse off in 2003, after 25 years of neoliberalism, than they had been in 1978, and the next twenty per cent were only marginally better off.

\begin{tabular}{|c|c|c|c|c|c|c|c|}
\hline \multicolumn{8}{|c|}{$\begin{array}{l}\text { Table } 1 \\
\text { Average Market Income (\$) } \\
2008 \text { constant dollars }\end{array}$} \\
\hline & 1978 & 1983 & 1988 & 1993 & 1998 & 2003 & 2008 \\
\hline Lowest quintile & 3,500 & 2,400 & 2,900 & 1,200 & 1,300 & 3,000 & 3,700 \\
\hline Second quintile & 26,100 & 21,100 & 22,900 & 16,100 & 17,300 & 20,900 & 23,400 \\
\hline Third quintile & 48,700 & 43,500 & 46,300 & 38,500 & 39,900 & 43,300 & 47,100 \\
\hline Fourth quintile & 71,000 & 67,200 & 72,100 & 64,800 & 68,000 & 71,800 & 77,500 \\
\hline Highest quintile & 122,200 & 120,200 & 128,500 & 120,700 & 138,200 & 148,400 & 164,700 \\
\hline
\end{tabular}

Statistics Canada Table 202-0701

Second, the share of market income gains in the neoliberal period is also increasingly hoarded by the wealthy, all while no improvement in the position of the poorest has been made, and middle income earners have increasingly lost ground over the past thirty years (see table 2). In 1978 the highest income quintile captured 45 percent of all income in Canada, yet by 2008 this share had increased to 52.1 percent. The lowest income quintile had a 1.3 percent share in 1978 , and this remained nearly identical in 2008 (1.2 percent). As for the other 60 percent of Canadians - second, third, and fourth income quintiles experienced a loss in their share of total income over that same period, by 2.2 percent, 3 percent, and 1.6 percent respectively. 
Socialist Studies / Études socialistes 7(1/2) Spring/Fall 2011: 42-64

\begin{tabular}{|l|l|l|l|l|l|l|}
\hline $\begin{array}{l}\text { Table 2 } \\
\text { Share of Market Income (\%) }\end{array}$ & $\mathbf{1 9 7 8}$ & $\mathbf{1 9 8 3}$ & $\mathbf{1 9 9 3}$ & $\mathbf{1 9 9 8}$ & $\mathbf{2 0 0 3}$ & $\mathbf{2 0 0 8}$ \\
\hline & 1.3 & 0.9 & 0.5 & 0.5 & 1 & 1.2 \\
\hline Lowest quintile & 9.6 & 8.3 & 6.7 & 6.5 & 7.3 & 7.4 \\
\hline Second quintile & 17.9 & 17.1 & 16 & 15.1 & 15.1 & 14.9 \\
\hline Third quintile & 26.1 & 26.4 & 26.9 & 25.7 & 25 & 24.5 \\
\hline Fourth quintile & 45 & 47.2 & 50 & 52.2 & 51.6 & 52.1 \\
\hline Highest quintile & & & & & & \\
\hline
\end{tabular}

Statistics Canada Table 202-0701

Similar to market incomes, average after-tax incomes are also on the rise in Canada, growing by almost 17 percent between 1978 and 2008, from $\$ 51,000$ to $\$ 59,500$ (in 2008 constant dollars). ${ }^{8}$ Under the Keynesian welfare state model, some measure of market income inequality was intentionally reduced through the implementation of progressive taxation systems. In the neoliberal era redistribution still occurs, yet after-tax income inequalities are growing. The Canadian state is therefore implicated in their growth. As table 3 indicates below, the average aftertax income of the wealthiest 20 percent has increased by 29 percent $(\$ 29,400)$ since 1978 , while the after-tax incomes of the poorest have increased on average by only 20 percent $(\$ 2,400)$.

\begin{tabular}{|l|l|l|l|l|l|l|l|}
\hline $\begin{array}{l}\text { Table } 3 \\
\text { Average After-Tax Income (\$) } \\
\text { 2008 constant dollars }\end{array}$ \\
\hline & $\mathbf{1 9 7 8}$ & $\mathbf{1 9 8 3}$ & $\mathbf{1 9 8 8}$ & $\mathbf{1 9 9 3}$ & $\mathbf{1 9 9 8}$ & $\mathbf{2 0 0 3}$ & $\mathbf{2 0 0 8}$ \\
\hline Lowest quintile & 12,100 & 12,200 & 13,900 & 12,600 & 11,800 & 13,200 & 14,500 \\
\hline Second quintile & 30,000 & 27,500 & 28,900 & 26,100 & 26,500 & 28,900 & 31,500 \\
\hline Third quintile & 46,500 & 42,700 & 44,000 & 40,000 & 40,700 & 44,300 & 48,500 \\
\hline Fourth quintile & 63,600 & 59,900 & 61,900 & 57,500 & 59,900 & 64,900 & 71,200 \\
\hline Highest quintile & 102,500 & 98,600 & 101,600 & 95,500 & 106,500 & 117,500 & 131,900 \\
\hline
\end{tabular}

Statistics Canada Table 202-0701

Despite now having a taxation system that does not significantly dampen disparities, and keeping in mind that the after-tax incomes of the bottom 20 percent remain at near subsistence levels, it is worth pointing out how important this vestige of the Keynesian welfare state remains. Comparing the lowest quintile table 1 figures to those of table 3 makes it evident that

\footnotetext{
${ }^{8}$ After tax income is defined as total income minus income tax. (Total income is composed of market income plus government transfers.)
} 
redistribution is essential for propping up purchasing power and providing for some modicum of social wellbeing given the meagre income secured by those pushed to the margins of the labour market in Canada.

The share of after-tax incomes is also growing increasingly uneven, although the magnitude of this disparity is lower. The share of income captured by the lowest quintile remains flat (increasing by only 0.2 percent over 30 years), while the highest quintile has experienced gains of 4 percent and the middle 60 percent have lost 4.3 percent of their share of total after tax-income in Canada (table 4).

\begin{tabular}{|l|l|l|l|l|l|l|l|}
\hline $\begin{array}{l}\text { Table } \mathbf{4} \\
\text { Share of after-tax income (\%) }\end{array}$ & $\mathbf{1 9 7 8}$ & $\mathbf{1 9 8 3}$ & $\mathbf{1 9 8 8}$ & $\mathbf{1 9 9 3}$ & $\mathbf{1 9 9 8}$ & $\mathbf{2 0 0 3}$ & $\mathbf{2 0 0 8}$ \\
\hline & 4.7 & 5.1 & 5.5 & 5.5 & 4.8 & 4.9 & 4.9 \\
\hline Lowest quintile & 11.8 & 11.4 & 11.5 & 11.3 & 10.8 & 10.7 & 10.6 \\
\hline Second quintile & 18.3 & 17.7 & 17.6 & 17.3 & 16.6 & 16.5 & 16.3 \\
\hline Third quintile & 25 & 24.9 & 24.7 & 24.8 & 24.4 & 24.1 & 23.9 \\
\hline Fourth quintile & 40.3 & 40.9 & 40.6 & 41.2 & 43.4 & 43.7 & 44.3 \\
\hline Highest quintile & 40.3 &
\end{tabular}

As helpful as the quintile breakdown is for uncovering income disparities, what this measurement obscures is just how much better off the very highest income earners in Canada are. Amongst the richest 5 percent of the population, the top 1 percent captured more than 90 percent of all income gains made by this group, and half of that was absorbed by the richest 0.1 percent (Mackenzie 2009b).

Stagnant Real Wages for Most Canadians, but the Rich Keep Getting Richer Not only are disparities amongst income groups on the rise in Canada, but real hourly wages increased by only 0.8 percent per year compared to increased labour productivity averaging 1.3 percent per annum between 1981 and 2008 (IOW 2009, 15). Thus, Canadian median wages and salaries, adjusted for inflation, have not grown for thirty years (Laxer 2009, 54). This is consistent with Marx's (1977) description of exploitation - the extraction of absolute surplus value and relative surplus value from labour. The former is increased through a lengthening of the working day and the latter through an increase in productivity. Chernomas (1999) argued that both are salient features of production under neoliberalism, more people 
now do work longer hours, and wages have not improved despite rising productivity.

It should come as no surprise that the most affluent are exempt from these stagnant wage trends, yet it is startling to see just how much richer the rich have become. In 1995 the average total compensation of the 50 highest paid executives in Canada was $\$ 2.66$ million, roughly 85 times the pay of the average worker; by 2007 they were making 398 times the average amount (Mackenzie 2009b). The average earnings of the top 100 Canadian CEOs even increased by 22 percent in one year alone - from $\$ 8.5$ million in 2006 to $\$ 10,408,054$ in 2007 (ibid). The 2009/10 recession also emphasized the level economic security experienced by the most affluent - in 2009 Canada's top 100 CEOs earned 155 times what the average Canadian earned, up from 104 in 1998 (Mackenzie 2011).

\section{Wealth Distribution}

Similar to income distribution, wealth concentration is on the rise. The wealthiest Canadians continue to grow disproportionately wealthy and have captured an ever larger share of total wealth generated during the neoliberal era. Understanding what is happening with the distribution of wealth in this country is important. It helps shed light on the implications of state austerity and neoliberal wage-compression, given that working class households must now borrow in order to maintain their standard of living in the face of stagnant or declining real wages and the retreat of welfare state support. In Canada household debt as a percentage of personal disposal income was roughly 80 percent in 1990, yet increased to 100 percent by 2002, and reached nearly 140 percent by 2008 (Baragar 2009,82 ). As a corollary, the personal savings rate in Canada dropped from 20.2 percent of disposable income in 1982, to below 10 percent in 1994, and finally to a low of 2 percent in 2005 (ibid). The consequences of the neoliberal high-debt, stagnant wage model were made clear during the most recent financial crisis: many households borrowed against the value of their homes, maxed out their credit cards, and had little or no savings to cushion the blow once the bubble burst.

Tracking changes in wealth distribution thus provides some insight into the economic (in)security of Canadians. Wealth can be drawn on to cushion the blow of economic downturns, and also reduces dependence on the labour market by, for example, allowing one the flexibility to reduce work hours, or to pursue self-employment (Morissette and Zhang 2006). A lack of assets or high levels of personal indebtedness eliminates these options. 
Since 1984 the median wealth of the bottom 40 percent of Canadians has declined, in some cases dramatically. Between 1984 and 2005 , the level of indebtedness for bottom 10 percent of households has increased on average by $\$ 7,500$; and for the next ten percent wealth was nearly completely eliminated. The top 10 percent, by contrast, nearly doubled their average household wealth, as it increased by $\$ 659,020$ in that same period (table 5).

\begin{tabular}{|l|l|l|l|}
\hline $\begin{array}{l}\text { Table 5 } \\
\text { Median Wealth (2005 \$) }\end{array}$ & $\mathbf{1 9 8 4}$ & $\mathbf{1 9 9 9}$ & $\mathbf{2 0 0 5}$ \\
\hline & $-2,100$ & $-6,570$ & $-9,600$ \\
\hline Bottom 10\% & 780 & 120 & 10 \\
\hline Second & 7,770 & 6,820 & 6,000 \\
\hline Third & 24,630 & 26,150 & 25,500 \\
\hline Fourth & 52,260 & 57,120 & 63,250 \\
\hline Fifth & 83,130 & 93,850 & 109,050 \\
\hline Sixth & 120,690 & 148,610 & 173,590 \\
\hline Seventh & 170,210 & 221,770 & 263,000 \\
\hline Eighth & 256,740 & 344,890 & 413,750 \\
\hline Ninth & 534,980 & 723,590 & $1,194,000$ \\
\hline Top 10\% & & \\
\hline \multicolumn{2}{|l|}{ Morissette \& Zhang. 2006. }
\end{tabular}

Wealth has also grown more concentrated during the neoliberal period. As indicated on table 6, the bottom forty percent have maintained roughly the same relative share of wealth over the neoliberal period, the next fifty percent have lost some ground, and the top 10 percent of Canadian households are now capturing a greater share of total wealth (increasing by 6.4 percent). 
Socialist Studies / Études socialistes 7(1/2) Spring/Fall 2011: $42-64$

\begin{tabular}{|l|l|l|l|}
\hline $\begin{array}{l}\text { Table } 6 \\
\text { Share of Wealth (\%) }\end{array}$ & $\mathbf{1 9 8 4}$ & $\mathbf{1 9 9 9}$ & $\mathbf{2 0 0 5}$ \\
\hline & -0.5 & -0.6 & -0.6 \\
\hline Bottom 10\% & 0.1 & 0 & 0 \\
\hline Second & 0.5 & 0.4 & 0.2 \\
\hline Third & 1.7 & 1.3 & 1.1 \\
\hline Fourth & 3.5 & 2.8 & 2.5 \\
\hline Fifth & 5.6 & 4.7 & 4.4 \\
\hline Sixth & 8.2 & 7.4 & 6.9 \\
\hline Seventh & 11.5 & 11 & 10.5 \\
\hline Eighth & 17.5 & 17.4 & 16.8 \\
\hline Ninth & 51.8 & 55.7 & 58.2 \\
\hline Top 10\% & & & \\
\hline \multicolumn{2}{|c|}{ Morissette and Zhang. 2006. } &
\end{tabular}

\section{Welfare Incomes}

The neoliberal policy message is clear: securing employment through the labour market must be encouraged, irrespective of the social costs. The notion that the market alone should be relied on for wellbeing might initially appear farcical in the face of decades-long stagnant or declining market incomes and ever-growing wealth concentrations (see tables 1 and 5); yet it is a message that is powerfully reinforced through decades of fiscal austerity, leading to a dramatic decline in the generosity of welfare benefits, "making life more difficult for the nearly 1.7 million children, women and men who rel[y] on welfare" (NCW 2007, 66). ${ }^{9}$ The annual Welfare Incomes ${ }^{10}$ publication produced by the National Council of Welfare (e.g. NCW 2007, 2010) documents the implications of this austerity. For many family scenarios, welfare incomes in 2006 and 2007 were at their lowest point since 1986 (NCW 2007, 68). The situation improved slightly in 2009 as welfare incomes were higher than in 2008, yet nonetheless they remained "consistently far below most socially accepted measures of adequacy" (NCW 2010, v). This decline can be attributed mainly to rising

${ }^{9}$ The 1996 federal spending and program changes that were made with the introduction of the Canada Health and Social Transfer (CHST) allowed for considerable experimentation by provinces in the redesigning of assistance programs. Along with the tightening of eligibility and benefit levels came a dramatic reduction in the number of Canadians able to rely on government assistance. Since then the number of welfare recipients have been cut in half, declining from just over 3 million people in 1995 to 1.68 million in 2005 (NCW 2006).

${ }^{10}$ Welfare incomes are defined as social assistance plus child benefits and tax credits. 
inflation, as the majority of welfare incomes did not keep pace with the 45.9 percent increase in the cost of living that occurred between 1990 and 2009. This left many worse off now than recipients in previous decades, with welfare incomes dropping by 20 percent in some cases (NCW 2010, vii).

Single people classified as 'employable' fare the worst. Depending on the measure used, this family type receives an income that is between 24 percent (at worst) and 64 percent (at best) of the poverty line. These incomes amount to only 15 to 38 percent of the after-tax income of average Canadian single member households, "making it apparent just how excluded some social assistance recipients are from mainstream Canadian life" (NCW 2010, viii). Although other family types (such as a single person with a disability, a lone parent household, or a couple with two children or more) may fare marginally better, it is worth emphasizing that poor economic conditions (the crisis and recession) have left many Canadians with no option but to turn to social assistance once their Employment Insurance benefits have run out.11 These individuals are thus doubly punished, first by the market and then by the state as dismal welfare benefits push them far below the poverty line.

On top of the reduced purchasing power and eroded standard of living experienced by welfare recipients, those in need of social assistance must now also contend with more punitive, workfare-oriented social programs which make qualifying for and maintaining assistance very difficult, especially for the homeless (Wallace et al. 2006; Bezanson 2006). Changes made at the provincial level since the 1990s have been dramatic. In British Columbia neoliberal program reform has been described as "unprecedented in Canada" as eligibility rules have been tightened and the application process altered such that those most in need of help are "discouraged, delayed and denied" and many are "diverted to homelessness, charities, and increased hardship" (see Wallace et al. 2006, 6-7). Thus austerity is not only a means to an end (lower government debt/deficits), but is also tied into a social shift in which economic security is far less assured and precariousness is reinforced.

\footnotetext{
${ }^{11}$ Employment Insurance has also become far less generous, with 2008 coverage reduced, duration of benefits decreased, and qualification period extended compared to 1981 levels (see Sharpe and Arsenault 2009).
} 
Socialist Studies / Études socialistes 7(1/2) Spring/Fall 2011: 42-64

\section{Size of the Public Sector}

\section{Public Sector Employment}

Another implication of state spending austerity is a decline in the number of people working in the public sector. Government employment between 1990 and 1999 fell by 9 per cent (McBride 2005, 102). In the early 2000s this trend was reversed to a degree. The number of public sector employees at the provincial and federal level did increase in those years. However, as a percentage of the total labour force government employment seemed to have experienced a permanent decline: from 21.25 of the labour force in 1990, to 17.5 in 1999, to 17.0 in March 2003, and after years of "boom," only 18 percent in 2009 (compiled using Statistics Canada CANSIM data, table 183-0002 "Public Sector Employment"). Despite economic growth, the imprint of the public sector in employment terms was reduced. Future cuts to the public sector also appear imminent as the 2010-11 federal budget seeks to save $\$ 17.6$ billion over five years through "streamlining and reducing the operating and administrative costs of government departments" (Evans 2010).

Privatization

Privatization is promoted as a mechanism for reducing state debt/deficit levels and as a way of enhancing the efficiency of goods and services provision. The initial wave of privatization in Canada targeted federal and provincial Crown corporations, and was most popular from the mid-1980s to the mid-1990s (see McBride 2005, 103-4). Privatization tended to occur within sectors that were strategically important for the functioning of the Keynesian welfare state (e.g., energy and transportation). They were also the most potentially profitable sectors of direct state involvement and thus privatization proved to be a boon for the private sector while hardly being justifiable as a form of fiscal austerity given that a stream of remittances was been traded for a single (often devalued) lump sum payment.

Once the most promising state owned enterprises were sold, new forms of privatization by stealth began to emerge - such as public-private partnerships (P3s) with the for-profit private sector - which, despite being also justified under the rubric of fiscal austerity, are often far more costly (economically and socially) than traditional service and infrastructure delivery methods. Evidence of this abounds in the Canadian empirical record, two prime examples being the Abbotsford Regional Hospital P3 and the Brampton Civic Hospital P3. Despite claims that these P3s could deliver better value for money than the traditional public procurement 
method (Partnerships BC 2005; Daily Commercial News 2001), both actually ended up costing the taxpayer far more.

First, there are hidden fees that uniquely accompany P3s. With the Abbotsford hospital, the BC provincial government spent over \$7 million in administrative costs, and $\$ 24.7$ million on legal and consultant costs (Partnerships BC 2005, 34). Similarly, with the Brampton hospital, the Ontario provincial government paid \$33.9 million to advisors subsequent to the selection of the preferred bidder (Auerbach et al. 2003, 9).

Second, privately financed infrastructure also costs more due to the higher interest rates typically secured by private sector borrowers. Prior to 2007, private partner borrowing costs exceeded public costs by two percent, amounting to a 60 percent increase in total financing costs when measured in present value terms. This spread then increased to three or four percent on average in 2007-9 due to the global financial crisis, amounting to a 70 percent increase in total financing costs (Mackenzie 2009a, 2).

Finally, P3 value for money is often more rhetoric than reality. In the case of the Brampton P3 hospital, the Auditor General of Ontario found that going with the traditional method would have saved taxpayers $\$ 200$ million (Office of the Auditor General of Ontario 2008, 117). In analyzing the Abbotsford project, forensic accountants Parks and Terhart concluded that the methodology used to determine value for money was "biased in favour of the P3" and had best practice methods been followed, a publicly delivered hospital would have produced a savings of roughly $\$ 80$ million when compared to the P3 option $(2009,10)$. The higher costs associated with P3 use not only undermines proponents' arguments that they help curb wasteful government spending, but it also means that less is available to be spent on much needed social concerns and infrastructure projects.

\section{Conclusion}

The vast majority of Canadians are punished twice by the neoliberal regime, first through the labour market and then by the state. Structural changes in the economy have meant three decades of decline for the majority: stagnant or shrunken market incomes, a reduced share of national wealth, and a dramatic rise of household indebtedness. Alongside this inability of the neoliberal economy to provide for social wellbeing, state policy now punishes those most in need through draconian spending restraint and program reforms which actually push some families further into poverty. Yet this shift from a welfare state to a miserly state is far from consistent across social classes. Whether one considers the multi- 
billion dollar bailouts recently offered to leading capitalist sectors (auto and banking), or the ever-growing use of P3s that often throw millions of unnecessary taxpayer dollars into private coffers with each new project, neoliberal policy has proven quite generous for some. Further, in contrast to the income stagnation and wealth erosion experienced at the bottom and by the middle class over thirty years, the position of the wealthy has improved dramatically - incomes and assets are growing, as are their shares of each. Thus to the familiar neoliberal rhetoric of belt tightening and market-reliance must be added the reality of abundance and state support experienced by the few who benefit from its logic. Austerity has been a salient policy feature over the past thirty years, yet it has also been selective. Posing the question 'austerity for whom?' forces us to recognize that not only has this been a permanent feature of the neoliberal period for many but it is also inexorably intertwined with growing affluence experienced by those few who are most well off in Canadian society.

The neoliberal regime has triggered a series of regional crises which impoverished millions of people around the world, culminating a global financial crisis in 2007. For a time this crisis seemed to shake neoliberal certainties to their foundations. Emergency measures included bailouts, nationalizations, budgetary stimulus, financial easing and a host of other initiatives designed to get credit and job creation moving. Although a global recession did follow the financial crisis and credit-crunch, the stimulus packages put in place averted a more serious situation. However, these measures were intended to rescue the neoliberal project, not to bury it. Once slender signs of a recovery appeared, policy discussions turned to the issue of how quickly emergency measures could be terminated and "sound finance" restored. Meanwhile the vast sums expended in bailing out financial institutions deemed "too big to fail" had to be repaid. A new age of austerity looms in which state budgets and particularly social programs will be ravaged to pay for the excesses of financiers. So popular is the return to austerity that according to Paul Krugman (2010): "the idea that what depressed economies really need is even more suffering seems to be the new conventional wisdom". The new era of austerity, however, is nothing new. Looked at in historical context, it is simply a crisis-driven intensification of longer term trends that are intrinsic to the neoliberal model.

\section{Acknowledgements}

The authors would like to thank the journal's anonymous reviewers for their helpful suggestions. 
McBRIDE and WHITESIDE: Introduction: Austerity for Whom?

\section{References}

Auerbach, L.. 2003. Donner, A., Peters, D., Townson, M., Yalnizyan, A. Funding Hospital Infrastructure: Why P3s Don't Work, and What Will. Ottawa: Canadian Centre for Policy Alternatives.

Banting, Keith G. 1987. The Welfare State and Canadian Federalism. $2^{\text {nd }}$ ed. Montreal: McGill-Queen's University Press, 1987.

Banting, Keith G. 2005. “Canada: Nation-Building in a Federal Welfare State.” In Federalism and the Welfare State, ed. H. Obinger, S. Leibfried, and F. Castles, 89-137. Cambridge: Cambridge University Press.

Baragar, Fletcher. 2009. "Canada and the Crisis." In Bankruptcies \& Bailouts, ed. Julie Guard, Wayne Antony, and Cy Gonick, 77-105. Winnipeg: Fernwood Publishing.

BBC. 2011. "Banks agree Project Merlin lending and bonus deal," BBC News, 9 February 2011, http://www.bbc.co.uk/news/business-12402469.

BBC. 2010. “Spending Review 2010: George Osborne wields the axe,” BBC News, 20 October 2010, http://www.bbc.co.uk/news/uk-politics-11579979.

Beland, D. and F.V. de Chantal. 2004. "Fighting 'Big Government': Frames, Federalism, and

Social Policy Reform in the United States." Canadian Journal of Sociology 29, no. 2: 241264.

Bezanson, Kate. 2006. Gender, the State, and Social Reproduction. Toronto: University of Toronto Press.

Campeau, Georges. 2005. From UI to EI: Waging War on the Welfare State. Vancouver: UBC Press.

Chernomas, Robert. 1999. "Inequality as a Basis for the US Emergence from the Great Stagnation.” International Journal of Health Services 29, no. 4: 821-32.

Clarkson, Stephen. 1993. “Constitutionalizing the Canadian-American Relationship.” In Canada under Free Trade, eds. Duncan Cameron and Mel Watkins, 3-20. Toronto: Lorimer.

Contreras, Russell. 2010. “Audacity of 'austerity,' 2010 Word of the Year," Yahoo News, 20 December 2010, http://news.yahoo.com/s/ap/20101220/ap_on_re us/us word of the year.

Daily Commercial News. 2001. “Ontario plans first privately built hospital.” Daily Commercial News and Construction Record 74, no. 235: A5.

Elmhirst, Sophie. 2010. "Word Games: Austerity," New Statesman, 24 September 2010, http://www.newstatesman.com/ideas/2010/09/austerity-word-red-conference.

Evans, Peter. 2010. “Steady Budget Offers Few Surprises,” CBC News, 5 March 2010.

Fudge, Derek with the assistance of John Brewin. 2005. Collective Bargaining in Canada: Human Right or Canadian Illusion. Ottawa: NUPGE and UFCW Canada.

Gill, Stephen. 1995. “Globalisation, Market Civilisation and Disciplinary Neoliberalism.” Millennium 5, no. 24: 399-423. 
Graefe, Peter. 2006. "The Social Economy and the American Model." Global Social Policy 6, no. 2: 197-219.

Grinspun, Ricardo and Robert Kreklewich. 1994. "Consolidating Neoliberal Reforms: 'Free Trade' as a Conditioning Framework." Studies in Political Economy 43: 33-61.

Hacker, J. S. 2004. "Privatizing Risk without Privatizing the Welfare State: The Hidden Politics of Social Policy Retrenchment in the United States." American Political Science Review 98, no. 2: 243-260.

Hall, Peter A. and David Soskice. 2001. Varieties of Capitalism: The Institutional Foundations of Comparative Advantage. Oxford: Oxford University Press, 2001.

Houle, François. 1990. "Economic Renewal and Social Policy.” In Canadian Politics: An Introduction to the Discipline, eds. Alain G. Gagnon and James P. Bickerton, 424-445. Peterborough, ON: Broadview.

Institute of Wellbeing (IOW). 2009.“How are Canadians Really Doing?” June 10, 2009, www.ciw.ca/en/TheCanadianIndexofWellBeing.aspx.

Jenson, Jane and Denis Saint Martin. 2003. "New Routes to Social Cohesion? Citizenship and the Social Investment State." Canadian Journal of Sociology 28, no. 1: 77-99.

Jessop, Bob. 2006. "Spatial Fixes, Temporal Fixes and Spatio-Temporal Fixes." In David Harvey: a critical reader, eds. Noel Castree and Derek Gregory, 142-66. Malden, MA: Wiley-Blackwell.

Kroeger, Arthur. 1996. "Changing Course: The Federal Government's Program Review of 1994-95." In Hard Choices or No Choices: Assessing Program Review, eds. Amelita Armit and Jacques Bourgault, 21-28. Toronto: Institute of Public Administration of Canada..

Krugman, Paul. 2010. “The Pain Caucus,” The New York Times, Op-ed, 30 May 2010, http://www.nytimes.com/2010/05/31/opinion/31krugman.html? r=1.

Laxer, James. 2009. Beyond the Bubble. Toronto: Between the Lines.

Mackenzie, Hugh. 2011. Canada's Best Paid CEOs 'recession' proof. Toronto: Canadian Centre for Policy Alternatives, National Office, 3 January 2011.

Mackenzie, Hugh. 2009a. Bad Before, Worse Now. Ontario: Hugh Mackenzie and Associates.

Mackenzie, Hugh. 2009b. Banner Year for Canada's CEOs. Toronto: Canadian Centre for Policy Alternatives, National Office, 02 January 2009.

Mahon, Rianne. 2008. "Babies and Bosses: Gendering the OECD’s Social Policy Discourse." In The OECD and Transnational Governance, eds. Rianne Mahon and Stephen McBride, 260-75. Vancouver: UBC Press.

Maslove, Allan M., Michael J. Prince, and G. Bruce Doern. 1986. Federal and Provincial Budgeting. Toronto: University of Toronto Press, 1986.

Marx, Karl. 1977. Capital, volume 1. New York: Vintage.

McBride, Stephen. 2005. Paradigm Shift. $2^{\text {nd }}$ ed. Halifax: Fernwood.

McBride, Stephen. 1992. Not Working: State, Unemployment, and Neo-Conservatism in Canada. Toronto: University of Toronto Press. 
McBRIDE and WHITESIDE: Introduction: Austerity for Whom?

McBride, Stephen and Heather Whiteside. 2011. Private Affluence, Public Austerity: Economic Crisis and Democratic Malaise in Canada. Halifax: Fernwood.

McBride, Stephen and John Shields. 1997. Dismantling a Nation: Canada and the New World Order. $2^{\text {nd }}$ ed. Halifax: Fernwood.

Mishra, Ramesh. 1990. The Welfare State in Capitalist Society: Policies of Retrenchment and Maintenance in Europe, North America and Australia. London: Harvester Wheatsheaf Press.

Morissette, Rene and Xuelin Zhang. 2006. "Revisiting Wealth Inequality." Perspectives (December). Ottawa: Statistics Canada.

National Council of Welfare (NCW). 2010. Welfare Incomes 2009. Ottawa: National Council of Welfare.

National Council of Welfare (NCW). 2007. Welfare Incomes 2006 and 2007. Ottawa: National Council of Welfare.

National Council of Welfare (NCW). 2006. Fact Sheet: Number of People on Welfare. Ottawa: National Council of Welfare.

Office of the Auditor General of Ontario. 2008. Brampton Civic Hospital Public-Private Partnership 2009. http://www.auditor.on.ca/en/reports en/en10/403en10.pdf.

Panitch, Leo and Don Swartz. 2008. From Consent to Coercion: The Assault on Trade Union Freedoms. $3^{\text {rd }}$ ed. Toronto: University of Toronto Press.

Parks, R. and Terhart, R. 2009. Evaluation of Public-Private Partnerships: Costing and Evaluation Methodology. Report prepared for the Canadian Union of Public Employees, British Columbia, 5 January 2009.

Partnerships BC. 2005. Project Report: Achieving Value for Money Abbotsford Regional Hospital and Cancer Centre Project. Victoria, BC: Partnerships BC.

Peck, Jamie and Adam Tickell. 2002. “Neoliberalizing Space.” Antipode 34, no. 3: 380-404.

Phillips, Stephen. 2000. "The Demise of Universality: The Politics of Federal Income Security in Canada, 1978-1993." Paper presented at the annual meeting of the British Columbia Political Studies Association, Victoria, BC, May 2000.

Pierson, Paul. 1994. Dismantling the welfare state? : Reagan, Thatcher, and the politics of retrenchment. Cambridge: Cambridge University Press.

Porter, D and D. Craig. 2004. "The Third Way and the Third World: poverty reduction and social inclusion in the rise of 'inclusive' liberalism." Review of International Political Economy 11, no. 2: 387-423.

Prince, Michael J. 1999. "From Health and Welfare to Stealth and Welfare: Federal Social Policy, 1980-2000." In How Ottawa Spends 1999-2000, eds. Leslie A. Pal, 151-196. Toronto: Oxford University Press.

Sharpe, Andrew and Jean-Francois Arsenault. 2009. Living Standards: executive summary. Institute for Wellbeing, 10 June 2009.

Standing, G. 1999. Global Labour Flexibility. London: Macmillan.

Statistics Canada. n.d. Table 183-0002. "Public Sector Employment." 
Statistics Canada. n.d. Table 202-0701. "Market, total and after-tax income, by economic family type and income quintiles, 2008 constant dollars."

Torfing J. 2001."Path-Dependent Danish Welfare Reforms: The Contribution of the New Institutionalisms to Understanding Evolutionary Change." Scandinavian Political Studies 24, no. 4: 277-309.

Wallace, Bruce, Seth Kein, and Marge Reitsma-Street. 2006. Denied Assistance: closing the front door on welfare in BC. Canadian Centre for Policy Alternatives, British Columbia. 